\title{
COMPUTER SIMULATION AIDED IMPROVEMENT OF SURFACE IRRIGATION EFFICIENCY
}

\author{
Mohsen A. El-Adl * \\ ABSTRACT
}

Under Egyptian old land circumstances, the simulation models technique may be more appreciable and less cost manner, to improve surface irrigation effectiveness and increase application efficiency. Forecasting using computer model for simulation of On-farm water management is important to design and evaluate the system application efficiency especially under many dependent factors that affect the system design.

The objective of the herein research is to improve surface border and furrow irrigation systems performance through simulation models. Field evaluation was carried out to generate data required for the model. The surface irrigation improvement computer aided design model was developed to simulate the performance of the border and furrow irrigation systems under various conditions. Models' predictions matched actual data with minimum acceptable errors.

Key words: surface irrigation improvement - simulation model irrigation efficiency

\section{INTRODUCTION}

\begin{abstract}
Ourface irrigation methods are characterized by low application

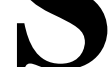
efficiency. Despite the 6 million feddan irrigated by surface irrigation; and except of few publications, the research work over the last one and half decades was devoted to modern irrigation methods in new land. Improving surface irrigation methods is of great importance especially in the light of secure and better use of water resources.

Alazba (1999) stated that several models with various solutions have been established. The Volume Balance Model (VBM) is commonly used in surface irrigation design, evaluation, and management, because the sophisticated models require extensive programming and high computer cost due to the long execution time.
\end{abstract}

* Assoc. Prof., Agric. Eng. Dept., Faculty of Agric., Mansoura University. 
The VBM was used to develop explicit advance solution. The proposed advance solution was developed assuming that the roughness is characterized by Manning equation; therefore, the solution is valid for cases where the bottom slope is not equal to zero. The method is not appropriate to conditions for which the inlet stream area changes dramatically with time.

Mailhol et al. (1997) showed that simplified analytical modeling options could be added to the basic advance-infiltration model for improving irrigation efficiency. The modeling option developed in this paper concerned with the prediction of cutoff time and irrigation performance for Closed End Furrows (CEF). The simplified analytical model for (CEF) based on the mass conservation principle was successfully compared to field tests and numerical simulations.

Connolly (1998) mentioned that the poor soil structure; i.e. aggregation and porosity, is widely acknowledged as a major limitation to infiltration, redistribution and storage of water in a soil profile, leading to more runoff and erosion, reduced available water for plants and reduced crop production. Models of soil-crop systems are useful tools for evaluating interactions between soil physical condition, climate management and crop growth. Mechanistic models were typically used for detailed simulations of soil water dynamics and more complex than functional models. No modeling approach suites all applications.

Clemmens et al. (1999) concluded that the factors that influence surface irrigation efficiency are numerous. Field length, basin width or furrow cross sectional shape, and slope defines the geometry. Soil infiltration and surface roughness parameters define the soil and crop conditions, while the inflow hydrograph defines the operation of the system. The only feasible way to study the combined influence of some of these variables or indeed all of them at the same time is through simulation models. This article provides an introduction to the application of this technology to improving surface-irrigation performance. Several empirical equations are available for evaluating the friction slope. The Manning equation is commonly used in surface irrigation, i.e.; 


$$
\mathrm{S}_{\mathrm{f}}=\frac{\mathrm{Q}^{2}\left(\frac{n}{c_{u}}\right)^{2}}{A^{2} \mathrm{R}^{4 / 3}}
$$

Where;

$\mathrm{S}_{\mathrm{f}}=$ friction loss per unit length (friction slope),

$\mathrm{Q}=$ flow rate, $\mathrm{L}^{3} / \mathrm{T}$

$\mathrm{A}=$ the cross-sectional flow area, $\mathrm{L}^{2}$

$\mathrm{R}=$ the hydraulic radius (area divided by wetted perimeter),

$\mathrm{n}=$ the Manning roughness coefficient,

$\mathrm{cu}=\mathrm{a}$ unit coefficient (1.0 for SI units, 1.486 for English units).

The Kostiakov infiltration function is frequently used to define infiltration as:

$$
\mathrm{D}=\mathrm{k} \mathrm{T}^{\mathrm{a}}
$$

Where;

$\mathrm{D}=$ cumulative infiltration, $\mathrm{m}$

$\mathrm{T}=$ the infiltration time, $\min$

$\mathrm{k}$ and $\mathrm{a}=$ empirical constants.

Strelkoff et al. (1999) pointed that the use of surface-irrigation simulation and design software is often hindered by the lack of appropriate field values for the infiltration and roughness parameters required as input. Moreover, in various places, for example, Egypt, as a consequence of local soils and cropping and cultural practices, the field conditions encountered can be quite different from those common in the U.S. Interactive field parameter evaluation software was developed as an aid for estimating these parameters from extensive field measurements. In the interactive process, the engineer is provided with information to assist in making his choices, but retains full control over the selection of parameter values in the empirical formulas used to describe infiltration and roughness. Parameter estimates in Egypt were validated by entry into the general surface irrigation simulation program, and subsequent comparison of the predicted and measured results. The procedure verifies both the parameter-estimation techniques and simulation program. The techniques and models described were presented in terms of Egyptian data, but were sufficiently general to be applicable anywhere. 
Dholakia et al. (1998) presented three computational models for simulation of border irrigation events. The governing equations of all three models were numerically solved using the explicit Mac-Cormack Finite difference method. All the three models simulated all the four phases of border irrigation event. The stability criterion of various models was also presented;

\section{1- Hydrodynamic model:}

$$
\begin{aligned}
& \frac{\partial \mathrm{h}}{\partial t}+\frac{\partial \mathrm{q}}{\partial x}+\mathrm{I}=0 \\
& \frac{\partial \mathrm{q}}{\partial t}+\frac{\partial}{\partial x}\left(\frac{\mathrm{q}^{2}}{h}+\frac{\mathrm{g} \mathrm{h}^{2}}{2}\right)-\mathrm{gh}\left(\mathrm{S}_{0}-\mathrm{S}_{\mathrm{f}}\right)-\mathrm{D}_{\mathrm{I}}=0
\end{aligned}
$$

Where;

$$
\begin{aligned}
\mathrm{D}_{\mathrm{I}} & =\text { account of momentum transfer associated with seepage } \\
& \text { outflow in x-direction } \\
x & =\text { distance along the borders }(\mathrm{m}) \\
\mathrm{t} & =\text { time }(\mathrm{s}) \\
\mathrm{h} & =\text { flow depth }(\mathrm{m}) \\
\mathrm{q} & =\text { discharge per unit width }\left(\mathrm{m}^{2} / \mathrm{s}\right) \\
\mathrm{g} & =\text { acceleration due to gravity }\left(9.81 \mathrm{~m} / \mathrm{s}^{2}\right) \\
\mathrm{I} & =\text { volumetric rate of infiltration per unit area }(\mathrm{m} / \mathrm{s}) \\
\mathrm{S}_{0} & =\text { slope of the border, } \\
\mathrm{S}_{\mathrm{f}} & =\text { friction loss per unit length (friction slope) }
\end{aligned}
$$

\section{2- Zero inertia model (Jaynes, 1986):}

$$
\frac{\partial \mathrm{h}}{\partial t}+\frac{\partial}{\partial x}\left(\mathrm{C}_{\mathrm{t}} \mathrm{h}^{5 / 3}\right)+\mathrm{I}=0
$$

Where;

$$
\begin{array}{ll}
\mathrm{C}_{\mathrm{t}} \mathrm{h}^{5 / 3} & =\text { discharge per unit width }\left(\mathrm{m}^{2} / \mathrm{s}\right), \\
\mathrm{h} & =\text { flow depth }(\mathrm{m}) .
\end{array}
$$

\section{3- Kinematics' wave model (Smith, 1972):}

$$
\frac{\partial \mathrm{h}}{\partial t}+\alpha_{1} \frac{\partial \mathrm{q}}{\partial x}\left(\mathrm{~h}^{\alpha_{2}}\right)+\mathrm{I}=0
$$

Where;

$$
\mathrm{h}=\text { flow depth }(\mathrm{m}) \text {, }
$$




$$
\begin{aligned}
& \alpha_{1}=\frac{\mathrm{S}_{0}^{1 / 2}}{\mathrm{n}}, \\
& \alpha_{2}=5 / 3
\end{aligned}
$$

Among the three models developed, the hydrodynamic finite difference model was found to be most suitable for the simulation of border irrigation event, though it takes a slightly more computational effort.

EI-Mowelhi et al. (1999-a) indicated that the amount of water applied under border system is positive correlated to irrigation run lengths, width and stream size, while the amount of water applied is negative correlated to different land leveling. They also added that, by applying continuous flow water border system, the water application efficiency is positive correlated to border width and land leveling, while is negative correlated to border length and stream size.

Zerihun et al. (2002) mentioned that in border irrigation, both time-based and distance-based cutoff criterion was used to time inflow cutoff. Each criterion has its own advantage and limitation. In this study the advantages and limitations of each cutoff criterion are discussed. The alternative optimality conditions were evaluated and compared.

Cahoon et al. (1995) were used furrow irrigation model to determine the relationship between the cutoff ratio (ratio of advance time to application time), the application efficiency of the low quarter, the exponent of the Kostiakov infiltration equation and the field slope. The furrow irrigation model and field trials were used to achieve the management recommendations to enhance system performance.

Tabuada et al. (1995-b) indicated that the use of empirical or semi-empirical infiltration equations only allows the computation of the infiltration volumes. While the equation taking into account specific initial and boundary conditions not only quantify infiltration volumes but also describe the water movement in soil. The two dimensional infiltration models is thus a useful tool for the study of infiltration in furrow irrigation.

Tabuada et al. (1995-a) reported that it is possible to optimize the space between furrows, the more favorable cross section and the optimal 
discharge to obtain good irrigation efficiency for a given plot with a corresponding slope and length.

Camacho et al. (1997) reported that the model calculates infiltration parameters from measured advance times in the field using a kinematics wave model that includes spatial and temporal variability of infiltration due to variation of the wetted perimeters. The model calculates cutback inflow rates to reduce runoff and the irrigation application time as a function of the required water depth.

Zin El-Abedin and Ismail (1999) examined a model for the changes in the discharge at each of the accumulative infiltration equations were plotted. The higher discharge, the less the time advance and the less the infiltrated depth. Logically, the more time water stays on the soil surface the deeper the water infiltrated. Similar results were obtained from field experiment in furrow system. In general, the model was capable of predicting the advance water curves of fronts for the different accumulative equations with the different discharge. The model gave very good prediction for the advance water.

El-Mowelhi et al. (1999-b) summarized that the Basin Computer Aided Design; (BASCAD) under estimated the water application efficiency for maize crop. The BASCAD program was over estimated the water distribution efficiency; however it needs some modification under condition of North Delta.

Oyonarte and Mateos (2003) reported that furrow irrigation models rarely consider the variability of the soil intake characteristics. However, such models are used more and more for the design, evaluation and management of surface irrigation systems.

Eldeiry et al. (2004) studied furrow irrigation system designs for clay soils in arid regions. A volume balance model was applied to simulate water flow in the furrow system. The design procedure requires the determination of the furrow geometry factors, the advance time, and the application efficiency.

The objective of this work was to develop simulation computer aided design models to improve surface border and furrow irrigation systems performance. Then to apply and validate models' outputs. 


\section{MATERIALS AND METHODS}

Surface irrigation systems improvement is most likely to result from the mathematical modeling and computational aids in order to observe a new insight into irrigation system performance. The basis of soil conservation service design is to classify soils into intake families. The Kostiakov's equation of these families as follows (Kostiakov, 1932):

$$
\mathrm{F}=\mathrm{a} \mathrm{T} \mathrm{T}^{\mathrm{b}}+\mathrm{c}
$$

Where;

$\mathrm{F}=$ the cumulative intake $(\mathrm{mm})$,

$\mathrm{T}=$ the time water is in contact with the soil (min),

$\mathrm{a}, \mathrm{b}$ and $\mathrm{c} \quad=$ constants unique to each intake family.

This program deals with border and furrow irrigation systems only.

\section{Border Irrigation System:}

\section{Opportunity time:}

The opportunity time required for intake of the selected net application depth can be estimated by solution of the cumulative intake equation (USDA, 1974 and Bassett et al., 1983):

$$
\mathrm{T}_{\mathrm{n}}=\left[\frac{\mathrm{F}_{\mathrm{n}}-\mathrm{c}}{\mathrm{a}}\right]^{1 / \mathrm{b}}
$$

\section{Where;}

$\mathrm{T}_{\mathrm{n}} \quad=$ the net opportunity time (min.);

$\mathrm{F}_{\mathrm{n}} \quad=$ the desired net application depth $(\mathrm{mm})$;

$\mathrm{a}, \mathrm{b}$ and $\mathrm{c}=$ constants unique to each intake family.

\section{Model objective:}

The border irrigation system is complex and dynamic system; therefore evaluation process is important to optimize the use of water and to improve its use efficiency. The objective of this model part of border irrigation method is to evaluate the design and to identify the design limitations for this system in order to improve system efficiency.

\section{Model description:}

The values of the experimental data were statistically analyzed. The input data that needed for the program were executed according to the mathematical equation requirements. The sequence of the used equations 
is shown in the flow chart Fig. (1) of the border irrigation system. The design procedures follow methods described by soil conservation service (USDA, 1974 and Bassett et al., 1983).

\section{Design equations:}

\section{A. The inflow rate:}

The inflow rate can be determined for a given net depth of application (USDA, 1974 and Bassett et al., 1983) from:

$$
\mathrm{Q}=\frac{0.00167 \mathrm{~F}_{\mathrm{n}} \mathrm{Lw}}{\left(\mathrm{T}_{\mathrm{n}}-\mathrm{T}_{\mathrm{L}}\right) \mathrm{E}}
$$

Where;

Q = inflow rate $\left(\mathrm{m}^{3} / \mathrm{s}\right)$,

$\mathrm{F}_{\mathrm{n}} \quad=$ the desired net application depth $(\mathrm{mm})$,

$\mathrm{L} \quad=$ the length of the border strip $(\mathrm{m})$,

$\mathrm{w} \quad=$ strip width $(\mathrm{m})$,

$\mathrm{T}_{\mathrm{n}} \quad=$ the opportunity time (min) required for the desired application depth.

$\mathrm{T}_{\mathrm{L}} \quad=$ the lag time ( $\left.\mathrm{min}\right)$ that water remains on the head end of the strip after inflow stops,

$\mathrm{E}=$ the water application efficiency $(\%)$.

Where; $\quad \mathrm{E}=\frac{\text { The desired net application depth }}{\text { The gross application depth }} \times 100$

\section{Lag time-low gradient borders:}

Lag time is significant in border strips with slopes of $0.4 \%$ or less. Lag time for such low gradient borders may be computed (USDA, 1974 and Bassett et al., 1983) from the following developed equations:

When Manning coefficient, $\mathbf{n}=\mathbf{0 . 0 4}$;

$$
\mathrm{T}_{\mathrm{L}}=0.0008 \mathrm{~S}_{0}^{-1.198} \quad \mathrm{R}^{2}=0.97
$$

When Manning coefficient, $\mathbf{n}=\mathbf{0 . 1 5}$;

$$
\mathrm{T}_{\mathrm{L}}=0.0005 \mathrm{~S}_{0}^{-1.459} \quad \mathrm{R}^{2}=0.99
$$

When Manning coefficient, $\mathbf{n}=\mathbf{0 . 2 5}$;

$$
\begin{aligned}
& \mathrm{T}_{\mathrm{L}}=0.0016 \mathrm{~S}_{0}^{-1.370} \quad \mathrm{R}^{2}=0.99 \\
& \mathrm{~T}_{\mathrm{L}}=\frac{\mathrm{n}^{1.2} \mathrm{Q}_{\mathrm{u}}^{0.5}}{120\left[\mathrm{~S}_{0}+\left(\frac{0.0094 \mathrm{n} \mathrm{Q}_{\mathrm{u}}^{0.175}}{\mathrm{~T}_{\mathrm{n}}^{0.088} \mathrm{~S}_{0}^{0.5}}\right)\right]^{1.6}}
\end{aligned}
$$




\section{Where;}

$$
\begin{array}{ll}
\mathrm{n} & =\text { Manning coefficient, } \\
\mathrm{T}_{\mathrm{L}} & =\text { lag time - low gradient borders }(\mathrm{min}), \\
\mathrm{Q}_{\mathrm{u}} & =\text { inflow rate per unit width }\left(\mathrm{m}^{2} / \mathrm{s} / \text { meter width }\right), \\
\mathrm{S}_{\mathrm{o}} & =\text { the border slope }(\mathrm{m} / \mathrm{m}), \text { and } \\
\mathrm{T}_{\mathrm{n}} & =\text { the opportunity time }(\mathrm{min}) \text { required for the desired } \\
& \text { application depth. }
\end{array}
$$

\section{Design limitations:}

The design inflow rate, depth of flow, border slope and length should not exceed established limitations using the following equations:

\section{1- Flow depth-low gradient borders:}

The depth of flow $(\mathrm{mm})$ at the upper end of border strips with slopes of $0.4 \%$ or less may be computed from the following equation (USDA, 1974 and Bassett et al., 1983):

$$
\mathrm{d}=2454 \mathrm{~T}_{\mathrm{L}}^{3 / 16} \mathrm{Q}_{\mathrm{u}}^{9 / 16} \mathrm{n}^{3 / 8}
$$

Where

$$
\begin{aligned}
& \mathrm{d}=\text { the depth of flow }(\mathrm{mm}) \\
& \mathrm{T}_{\mathrm{L}}=\text { the lag time }(\mathrm{min}) \\
& \mathrm{Q}_{\mathrm{u}}=\text { the unit inflow rate }\left(\mathrm{m}^{2} / \mathrm{s} / \text { meter width }\right), \text { and } \\
& \mathrm{n}=\text { the manning coefficient. }
\end{aligned}
$$

\section{2- Minimum depth of flow:}

The flow rate must be large enough to spread over the entire border strip. A smaller flow rate is needed on rough surface strips than is required on adequately graded and smooth strips. The minimum inflow rate per unit width can be computed, using the following equation (USDA, 1974 and Bassett et al., 1983):

$$
\mathrm{Q}_{\mathrm{u}} \min =\frac{5.95 \times 10^{-6} \mathrm{LS}_{0}^{0.5}}{\mathrm{n}}
$$

Where;

$$
\begin{aligned}
& \mathrm{Q}_{\mathrm{u}} \min =\text { minimum depth of flow }\left(\mathrm{m}^{2} / \mathrm{s} / \text { meter width }\right) \\
& \begin{array}{ll}
\mathrm{S}_{\mathrm{o}} & =\text { the border slope }(\mathrm{m} / \mathrm{m}), \\
\mathrm{n} & =\text { the manning coefficient, } \\
\mathrm{L} & =\text { the length of the border strip }(\mathrm{m}) .
\end{array}
\end{aligned}
$$




\section{3- Maximum slope:}

The maximum allowable slope $\left(\mathrm{S}_{0} \max \right)$ can be estimated from equation (17) (USDA, 1974 and Bassett et al., 1983):

$$
\mathrm{S}_{0} \max =\left(\frac{\mathrm{n}}{0.0117 \mathrm{E}} \cdot \frac{\mathrm{F}_{\mathrm{n}}}{\mathrm{T}_{\mathrm{n}}}\right)^{2}
$$

\section{Where:}

$\mathrm{F}_{\mathrm{n}}=$ the desired net application depth $(\mathrm{mm})$,

$\mathrm{T}_{\mathrm{n}}=$ the opportunity time (min) required for the desired application depth,

$\mathrm{n}=$ the Manning coefficient,

$\mathrm{E}=$ the water application efficiency $(\%)$.

\section{4- Maximum length:}

The theoretical maximum length $\left(\mathrm{L}_{\max }\right)$ is limited by the maximum allowable flow rate, as limited by the border ridge height on flat slopes. The permissible border length on soils of low intake rate and low slopes, as determined using equation (18) (USDA, 1974 and Bassett et al., 1983):

$$
\mathrm{L}_{\max }=\frac{\mathrm{Q}_{\mathrm{u}} \mathrm{E}\left(\mathrm{T}_{\mathrm{n}}-\mathrm{T}_{\mathrm{L}}\right)}{0.00167 \mathrm{~F}_{\mathrm{n}}}
$$

\section{Where:}

$$
\begin{array}{ll}
\mathrm{Q}_{\mathrm{u}} & =\text { the unit inflow rate }\left(\mathrm{m}^{3} / \mathrm{s} / \text { meter width }\right), \\
\mathrm{E} & =\text { the water application efficiency }(\%) \\
\mathrm{T}_{\mathrm{n}} & =\text { the opportunity time }(\min ) \text { required for the desired } \\
& \text { application depth, } \\
\mathrm{T}_{\mathrm{L}} & =\text { the lag time }(\mathrm{min}), \\
\mathrm{F}_{\mathrm{n}} & =\text { the desired net application depth }(\mathrm{mm}),
\end{array}
$$

On fields where the length of the border is fixed, the reduced inflow rate required can be estimated from (19) (USDA, 1974 and Bassett et al., 1983):

$$
Q_{u e}=\frac{Q_{u}}{1+r_{i} r_{n}(1-E / 100)}
$$

Where;

$$
\begin{array}{ll}
\mathrm{Q}_{\mathrm{ue}} & =\text { the reduced unit inflow rate }\left(\mathrm{m}^{2} / \mathrm{s} / \text { meter width }\right), \\
\mathrm{Q}_{\mathrm{u}} & =\text { the unit inflow rate for the border length without end }
\end{array}
$$


blocks $\left(\mathrm{m}^{2} / \mathrm{s} /\right.$ meter width),

$\mathrm{E}=$ the water application efficiency $(\%)$.

$r_{i} \quad=$ factor expresses the effect of intake on run off; 0.7,

$\mathrm{r}_{\mathrm{n}} \quad=$ factor expresses the effect of roughness on run off; 0.8 .

Fig. (1) shows the flow chart and the sequence of the used equations for border irrigation system.

\section{Furrow irrigation system:}

\section{Model objective:}

The length of furrow and irrigation inflow rate can be limited by many affecting factors as the size end chap of the field, intake rate, slope within the field. The objective of the model is to evaluate the actual irrigation performance parameters with those calculated by the program and increase the efficiency of furrow irrigation system under different factors that affecting the system design.

\section{Model description:}

The program has used the design equations for furrow irrigation to describe and evaluate the relations between length, inflow time, inflow rate, deep percolation, surface run off, and field application efficiency. The design procedures follow methods by soil conservation service (USDA, 1979 and Bassett et al., 1983). The sequence of the used equations shown in the flow chart of the furrow irrigation system, Fig. (2). The design equations that used to evaluate the system are presented under the following main topics:

\section{Adjusted wetted perimeter:}

The empirical relationship to calculate the adjusted (USDA, 1979 and Bassett et al., 1983) is:

$$
\mathrm{P}=0.265\left(\frac{\mathrm{Q} n}{\mathrm{~S}^{0.5}}\right)^{0.425}+0.227
$$

Where

$$
\begin{aligned}
& \mathrm{P}=\text { adjusted wetted perimeter }(\mathrm{m}) \\
& \mathrm{Q}=\text { the inflow rate }(1 / \mathrm{s}) \\
& \mathrm{n}=\text { the manning roughness coefficient, } \\
& \mathrm{S}=\text { the slope }(\mathrm{m} / \mathrm{m}) \text { or hydraulic gradient. }
\end{aligned}
$$

It can be noted that the value of (P) cannot exceed the furrow spacing (W). 


\section{The advance time:}

The time for water to advance to successive points along the furrows, from regression analysis of trail measurements, is a semi-logarithmic relationship of length, inflow rate and slope (USDA, 1979 and Bassett $\boldsymbol{e t}$ al., 1983):

$$
\mathrm{T}_{\mathrm{T}}=\frac{\mathrm{X}}{\mathrm{F}} \mathrm{e}^{\beta}
$$

and

$$
\beta=\frac{\mathrm{g} \mathrm{X}}{\mathrm{Q} \mathrm{S}^{1 / 2}}
$$

\section{Where}

$\mathrm{T}_{\mathrm{T}}=$ the advance time $(\mathrm{min})$,

$\mathrm{X}=$ the distance $(\mathrm{m})$ from upper end of the furrow to point $(\mathrm{X})$

(The maximum value of $\mathrm{X}$ is $\mathrm{L}$, the field length),

$\mathrm{Q}=$ the inflow rate $(1 / \mathrm{s})$,

$\mathrm{S}=$ the furrow slope $(\mathrm{m} / \mathrm{m})$, and

$\mathrm{F}$ and $\mathrm{g}=$ advance coefficients varying with furrow intake family.

\section{Net opportunity time:}

The opportunity time required for intake of the selected net application depth, $F_{n}$ can be estimated from equation (22)(USDA, 1979 and Bassett et al., 1983):

$$
\mathrm{T}_{\mathrm{n}}=\left[\frac{\mathrm{F}_{\mathrm{n}} \mathrm{W} / \mathrm{P}-\mathrm{c}}{\mathrm{a}}\right]^{1 / 6}
$$

\section{Where}

$\mathrm{T}_{\mathrm{n}}=$ the net opportunity time $(\mathrm{mm})$,

$\mathrm{F}_{\mathrm{n}}=$ the net application depth $(\mathrm{mm})$,

$\mathrm{W}=$ the furrow spacing $(=0.75 \mathrm{~m})$,

$\mathrm{P}=$ adjusted wetted perimeter $(\mathrm{m})$,

$\mathrm{a}, \mathrm{b}$ and $\mathrm{c}=$ Intake family coefficients.

\section{Design inflow time:}

Design inflow time is computed from (USDA, 1979 and Bassett et al., 1983) equation:

$$
\mathrm{T}_{1}=\mathrm{T}_{\mathrm{T}}+\mathrm{T}_{\mathrm{n}}
$$

\section{Where}

$\mathrm{T}_{1}=$ the design inflow time (min),

$\mathrm{T}_{\mathrm{T}}=$ the advance time $(\mathrm{min})$, and

$\mathrm{Tn}=$ net opportunity time ( $\mathrm{min})$. 


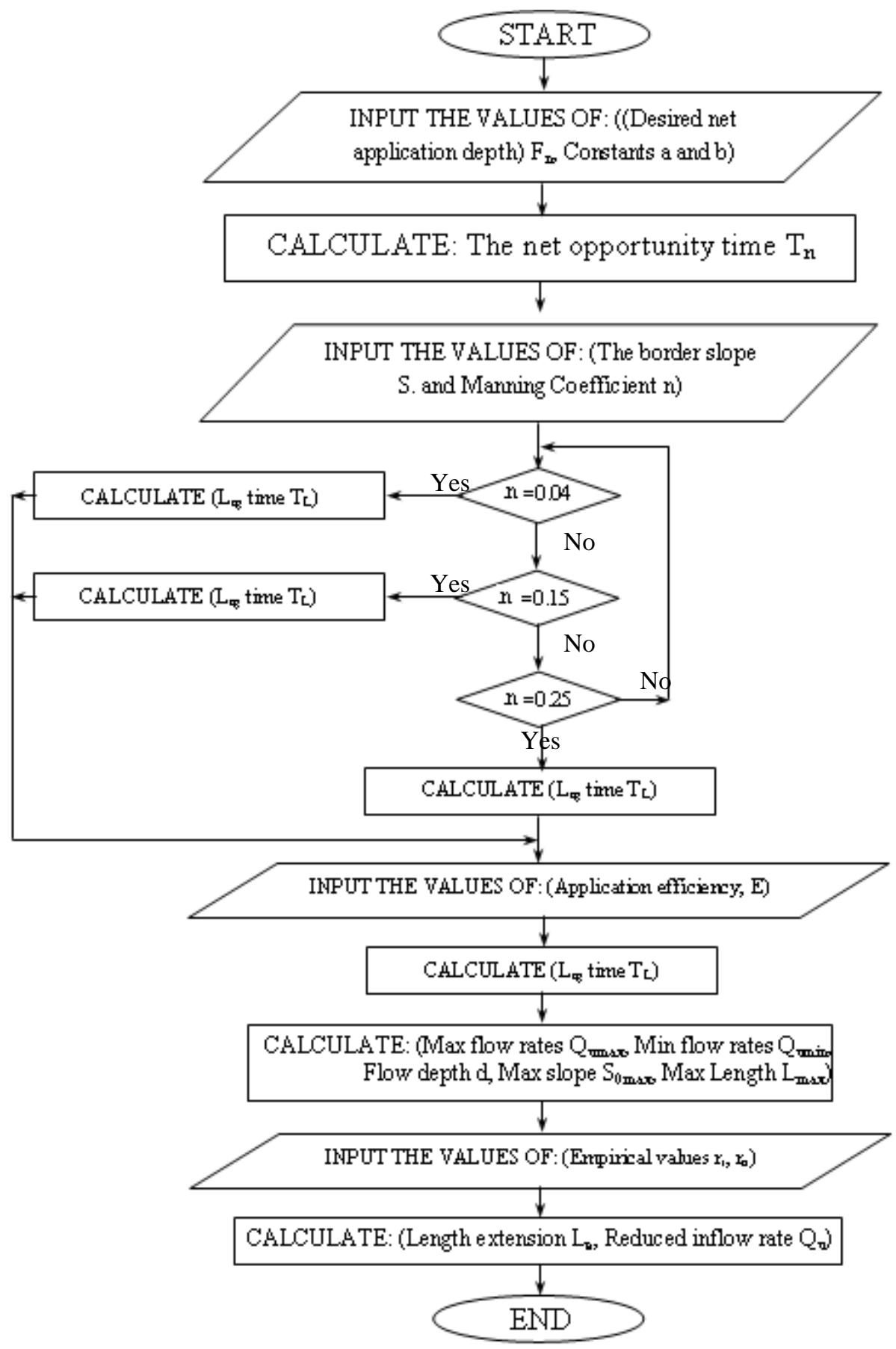

Fig. 1: The flow chart of program in case of border irrigation system. 


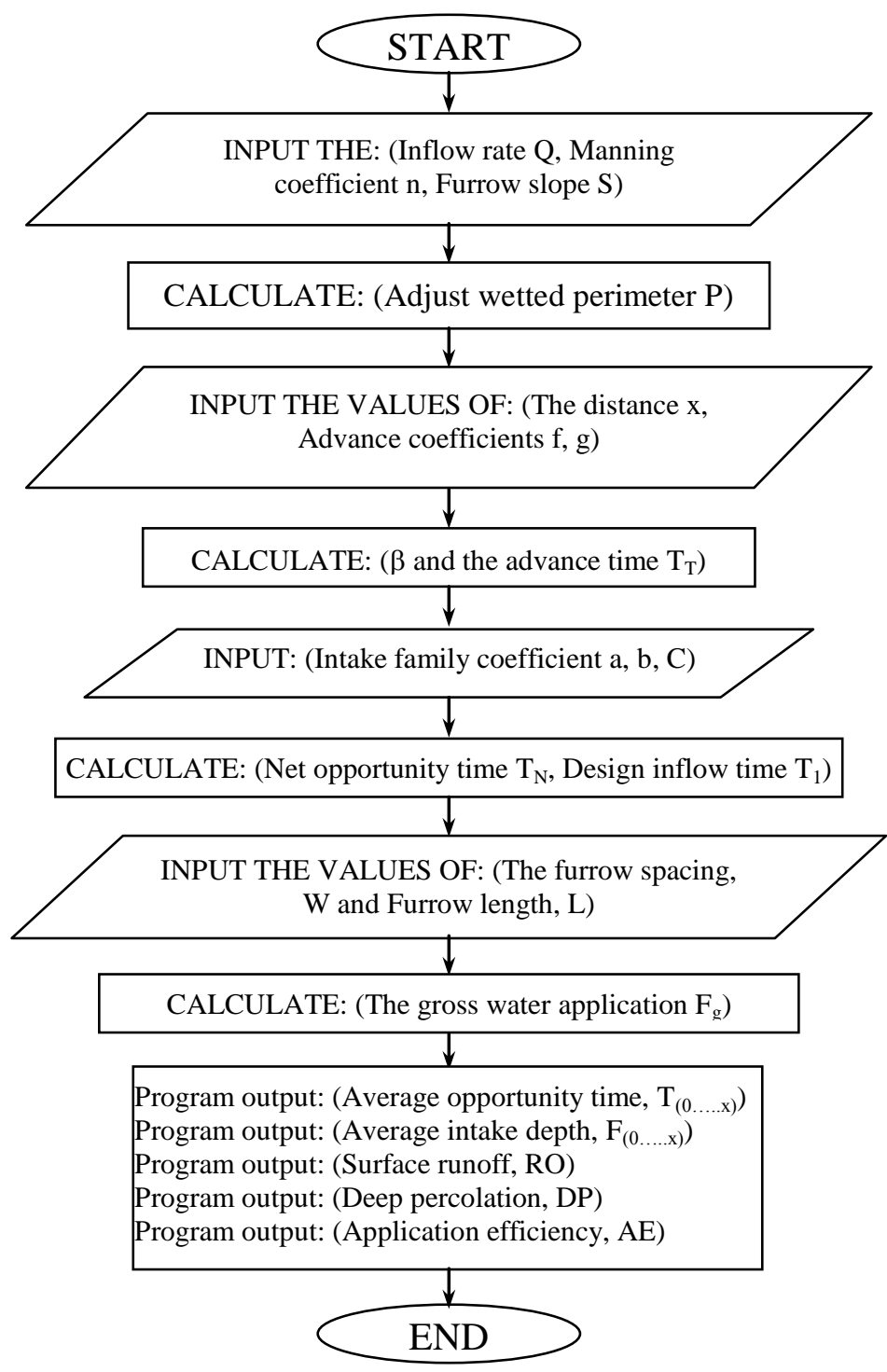

Fig. 2: The flaw chart of the program in case of furrow irrigation system.

\section{The gross water application:}

The gross water application is (USDA, 1979 and Bassett et al., 1983):

$$
\mathrm{F}_{\mathrm{g}}=\frac{60 \mathrm{Q} \mathrm{T}}{\mathrm{WL}}
$$

\section{Where}

$\mathrm{F}_{\mathrm{g}} \quad=$ the gross water application $(\mathrm{mm})$,

$\mathrm{Q}=$ the inflow rate $(1 / \mathrm{s})$, 
$\mathrm{T}_{1}=$ design inflow time (min),

$\mathrm{W}=$ the furrow spacing $(\mathrm{m})$, and

$\mathrm{L}=$ the furrow length $(\mathrm{m})$.

\section{Field experiment:}

Four field experiments (i.e. two for border and two for furrow) for models' validation were carried out on clayey soil. The testing area was $30 \mathrm{~m}$ length by $7 \mathrm{~m}$ width, $0.1 \%$ surface slope and discharge rate of $3 \mathrm{l} / \mathrm{s} / \mathrm{m}$ width of the strip.

\section{Error percentage}

The deference between the calculated results and model results was determined by using the following formula:

$$
\text { Error } \%=\frac{\text { Max. value }- \text { Min. value }}{\text { Max. value }}
$$

The sequence of the used equations is shown in the flow chart Fig. (2) for furrow irrigation system.

\section{RESULTS AND DISCUSSION}

\section{MODEL APPLICATION:}

Based on best values attained from field experiments the Surface Irrigation Improvement Computer Aided Design (SIICAD) was developed and implemented using the Visual Basic language (version 5). Table (1) shows the best values achieved from field experiments.

Table 1: Best attained values generated from field experiments and used to develop the SIICAD model.

\begin{tabular}{|l|c|c|}
\hline \multirow{2}{*}{\multicolumn{1}{|c|}{ Investigated parameter }} & \multicolumn{2}{c|}{ Type of irrigation system } \\
\cline { 2 - 3 } & Border & Furrow \\
\hline Desired net applied in depth $(\mathrm{mm})$ & $100-130$ & $130-150$ \\
\hline Intake family coefficient (a) & $3.76-6.042$ & $3.07-5.569$ \\
\hline Intake family coefficient (b) & $0.513-0.596$ & $0.564-0.611$ \\
\hline Ground slope (\%) & 0.1 & 0.1 \\
\hline Strip or furrow length (m) & 27 & 27 \\
\hline
\end{tabular}

The program was then executed to determine the system performance through the design limitations. The output design limitations of the border system are; the minimum and maximum in flow rate, the flow depth, the 
maximum slope and the maximum border length. The output design limitations of the furrow system are, the gross water application, the average opportunity time, the average intake depth, the surface runoff, the deep percolation and the application efficiency. The developed SIICAD model may be used to simulate the improvement of surface irrigation system.

\section{VALIDATION OF THE MODEL:}

In order to validate the SIICAD model, four field experiments were implemented to determine the accuracy of representative border and furrow design. This was done by comparing the calculated results and predicted output results. The sequence of the used equation is shown in the flow charts and Figs. (1 and 2) for border and furrow irrigation systems respectively. As shown in Table (2), the results revealed that the error percent between calculated and predicted program output results ranged between ( 0 -2l percent) for all parameters except the lag time $\mathrm{T}_{\mathrm{L}}$. The $\mathrm{T}_{\mathrm{L}}$ for first experiment gave $36.51 \%$ errors and for second experiment, $35.87 \%$ errors. While, $S_{0}$ max gave $100 \%$ error during first and $1.429 \%$ error for second experiments, respectively.

Also Table (3) shows the calculated results for furrow irrigation system during first and second experiments. The error percent for the adjusted wetted perimeter $P$, the advance time $T_{t}$, net opportunity time $T_{n}$, design inflow time $\mathrm{T}_{1}$ and Gross water application $\mathrm{F}_{\mathrm{g}}$ was recorded almost zero.

Table 2: Calculated, predicted output results and error percent of the program for the two field's experiments in case of border irrigation system.

\begin{tabular}{|l|c|c|c|c|c|c|}
\hline \multirow{2}{*}{ Program output } & \multicolumn{3}{c|}{ Experiment (1) } & \multicolumn{3}{c|}{ Experiment (2) } \\
\cline { 2 - 8 } & Calculated & Predicted & $\%$ Error & Calculated & Predicted & $\%$ Error \\
\hline $\begin{array}{l}\text { The net opportunity time } \\
\mathrm{T}_{\mathrm{n}}, \mathrm{min}\end{array}$ & 252.0 & 252.0 & 0.0 & 189.0 & 189.0 & 0.0 \\
\hline The lag time $\mathrm{T}_{\mathrm{L}}, \mathrm{min}$ & 2.0 & 3.1499 & 36.51 & 21.0 & 32.7471 & 35.87 \\
\hline Inflow rate $\mathrm{Q}, \mathrm{m}^{3} / \mathrm{s}$ & 0.00178 & 0.002 & 11 & 0.0029 & 0.003 & 3.3 \\
\hline Flow depth $\mathrm{d}, \mathrm{mm}$ & 6.501 & 7.10 & 8.44 & 21.82 & 24.83 & 12.12 \\
\hline Max. Slope $\mathrm{S}_{\mathrm{o}}, \mathrm{m} / \mathrm{m}$ & 0.000179 & 0.0001 & 44.13 & 0.0069 & 0.007 & 1.429 \\
\hline Max. Length $\mathrm{L}_{\max }, \mathrm{m}$ & $4699.5^{*}$ & 4736.19 & 0.78 & $4348 *$ & 4027.63 & 7.37 \\
\hline
\end{tabular}

* The theoretical maximum length $>30 \mathrm{~m}$ 
Table 3: Calculated, predicted output results and \% error of the program for the two field's experiments in case of furrow irrigation system.

\begin{tabular}{|l|c|c|c|c|c|c|}
\hline \multirow{2}{*}{\multicolumn{1}{|c|}{ Program output }} & \multicolumn{3}{c|}{ Experiment (1) } & \multicolumn{3}{c|}{ Experiment (2) } \\
\cline { 2 - 8 } & Calculated & Predicted & \% Error & Calculated & Predicted & \% Error \\
\hline The adj. wetted perimeter $\mathrm{P}, \mathrm{m}$ & 0.6941 & 0.6941 & 0.0 & 0.7682 & 0.7682 & 0.0 \\
\hline The advance time $\mathrm{T}_{\mathrm{t}}, \mathrm{min}$ & 3.64 & 3.60 & 1.09 & 3.30 & 3.03 & 0.08 \\
\hline Net opportunity time $\mathrm{T}_{\mathrm{n}}, \mathrm{min}$ & 103.3 & 103.33 & 0.0 & 70.92 & 70.02 & 0.02 \\
\hline Design inflow time $\mathrm{T}_{1}, \mathrm{~min}$ & 106.97 & 106.9 & 0.07 & 74.22 & 74.12 & 0.13 \\
\hline Gross water application $\mathrm{F}_{\mathrm{g}}, \mathrm{mm}$ & 855.75 & 855.05 & 0.08 & 593.80 & 593.80 & 0.0 \\
\hline
\end{tabular}

\section{REFERENCES}

Alazba, A.A. (1999). Explicit volume balance model Solution. J. of Irri. and Drainage Eng. Vol. 125(5): 273-279.

Bassett, D.L.; D.D. Fangmeier and T. Strelkoff (1983). Hydraulics of surface irrigation.

Cahoon, J.E.; P. Mandel and D.E. Eisenhauer (1995). Management recommendations for sloping blocked-end furrow irrigation. J. Applied Eng. In Agric., Vol. 11(4): 527-533.

Camacho, E.; C.P. Lucena; J.R. Canas and M. Alcaide (1997). IPE: Model for management and control of furrow irrigation in real time. Journal of Irrigation and Drainage Eng. Vol. 123(4): 264-269.

Clemmens, A.J.; Z. EI-Haddad and T.S. Strelkoff (1999). Assessing the potential for modern surface irrigation in Egypt. Transaction of the ASAE, Vol. 42(4): 995-1008.

Connolly, R.D. (1998). Modeling effects of soil structure on the water balance of soil-crop systems. Journal of Soil and Tillage Research, Vol. 48 pp: 1-19.

Dholakia, M.; R. Misra and M.S. Zaman (1998). Simulation of border irrigation system using explicit Mac Cormack finite difference method. Journal of Agric. Water Management, Vol. 36(3), pp: 181200 . 
Eldeiry, A. A. ; L. A. Garcia, A. S. A. El-Zaher, M. El-Sherbini Kiwan. (2004). Furrow irrigation system design for clay soils in Arid regions. Hydrology Days., Colardo State Univ., USA, P.42-54.

EI-Mowelhi, N.M.; M.S.M. Abo Soliman; M.M. Saied and S.H. Zaki (1999-a). Simulation modeling and field study of on-farm water management under surface irrigation system. Proceeding of the Third Conf. of On-Farm Irrigation and Agroclimatology. Jan. 2527, pp:86-97.

EI-Mowelhi, N.M.; M.M. Saied; M.S.M. Abo Soliman and S.A. Abd EIHafez (1999-b). Evaluation of irrigation performances using BASCAD Program under surface irrigation at North delta. Proceeding of the Third Conf. of On-Farm Irrigation and Agroclimatology. Jan. 25-27, pp:68-85.

Jaynes, D.B. (1986). Simple model of border irrigation. J. Irrig. Drain. Eng. 112(2), 172-184.

Jensen, M.E. (1983). Design and operation of farm irrigation systems.(Ed.). ASAE Monograph No. 3. (Michigan, USA.), 829 P.

Kostiakov A.N. (1932). On the dynamics of the coefficient of water percolation in soils and on the necessity for studying it from a dynamic point of view for purposes of amelioration. Trans. $6^{\text {th }}$ Comm. Internl. Soil Sci. Soc., Russian Part A: 17-21.

Mailhol, J.C.; M. Baqri and M. Lachhab (1997). Operative irrigation modeling for real-time applications on closed-end furrows. Journal of Irrigation and Drainage, Vol. 11, pp: 347-366.

Oyonarte, N.A. and L. Mateos (2003). Accounting for soil variability in the evaluation of furrow irrigation. Transactions of the ASAE, Vol. 46(1): 85-94.

Smith, R. F., (1972). Border irrigation advance and ephemeral flood waves. J. Irrig. Div. ASCE 98 (2), 289-305.

Strelkoff, T.S.; A.J. Clemmens; M. EI-Ansary and M. Awed (1999). Surface irrigation evaluation models : Application to level basins in Egypt. Transactions of the ASAE, Vol. 42(4):1027-1036. 
Tabuada, M.A.; Z.J.C. Rego; G. Vachaud and L.J. Pereira (1995-a). Modeling of furrow irrigation. Advance with two-dimensional infiltration. Journal of Agric. Water Management, Vol. 28, pp: 201221.

Tabuada, M.A.; Z.J.C. Regoi; G. Vachaud and L.S. Pereira (1995-b). Two-dimensional infiltration under furrow irrigation: Modeling, its validation and applications. J. of Agric. Water Management, Vol. 27, pp: 105-123.

USDA (1974). Border irrigation. Chapter 4, Section 15 (Irrigation) Soil conservation service. National Eng. Handbook.

USDA (1979). Furrow irrigation. Chapter 5, Section 15 (Irrigation) Soil conservation service. National Eng. Handbook.

Zerihun, D.; C.A. Sanchaez and K.L. Farell-Poe (2002). Analysis and design of border irrigation system. Paper Number 022177, ASAB, Annual Meeting, 2002.

Zin EI-Abedin, T.K. and S.M. Ismail (1999). Estimation and analysis of water advance in surface irrigation. Misr. J. Ag. Eng., 16(4):720744.



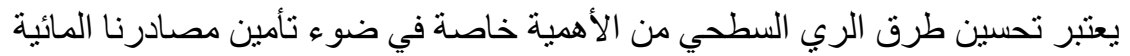

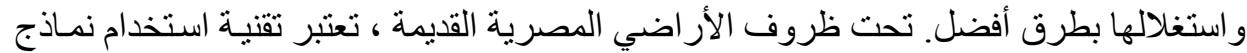

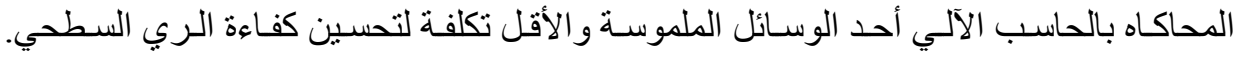

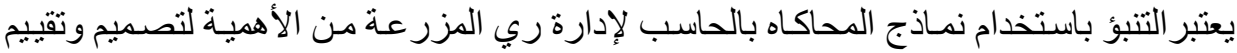

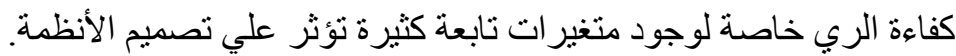



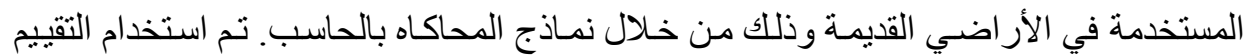

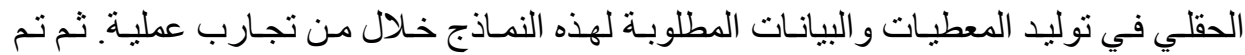

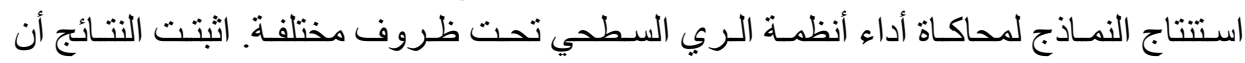
المخرجات المتوقعة من هذه النماذج تتو افق مع البيانات الحقيقية بأقل نسبة خطأ.

* أستاذ الهندسة الزر اعبة المساعدـ قسم الهندسة الزر اعية ـ كلية الزر اعة - جامعة المنصورة 